\title{
Detoxification of Nyar-Udota Cassava Variety in Zombo District by Fermentation
}

\author{
Benson Oloya ${ }^{1, *}$, Christopher Adaku ${ }^{2}$, Emmanuel Ntambi ${ }^{2}$, Morgan Andama ${ }^{3}$ \\ ${ }^{1}$ Department of Chemistry, Muni University, Arua, Uganda \\ ${ }^{2}$ Department of Chemistry, Mbarara University of Science and Technology, Mbarara, Uganda \\ ${ }^{3}$ Department of Biology, Mbarara University of Science and Technology, Mbarara, Uganda
}

Email address:

oloyabenson@gmail.com (B. Oloya),b.oloya@muni.ac.ug (B. Oloya)

${ }^{*}$ Corresponding author

\section{To cite this article:}

Benson Oloya, Christopher Adaku, Emmanuel Ntambi, Morgan Andama. Detoxification of Nyar-Udota Cassava Variety in Zombo District by Fermentation. International Journal of Nutrition and Food Sciences. Vol. 6, No. 3, 2017, pp. 118-121. doi: 10.11648/j.ijnfs.20170603.11

Received: February 13, 2017; Accepted: February 23, 2017; Published: March 9, 2017

\begin{abstract}
Fermentation is capable of detoxifying cassava cultivars. Cassava is one of the most important food crops in the world and in Uganda it is the second most consumed food crop after bananas. However, cassava has some toxic compounds, the cyanogenic glycosides such as linamarin and lotaustralin. Ingestion of the toxins in abundant quantities can be harmful to the health of both humans and animals. Cassava may hence, present a potential health risk to the consumers. Information regarding better detoxifying methods and processing conditions of cyanogenic glycosides content in cassava is vital for avoidance of health risks associated with cassava consumption. Accordingly, one local cultivar, Nyar-udota, was subjected to fermentation for detoxification of their cyanogenic content. Fermentation achieved significant detoxification of the cyanogenic glycosides in the cassava cultivar up to $64.7 \%$ and the decrease varied with period of fermentation.
\end{abstract}

Keywords: Cassava, Cyanogenic Potential, Detoxification, Fermentation

\section{Introduction}

Cassava is the third most key food source in the tropics after rice and maize and it is the staple food of at least 500 million people [1].

However, cassava contains some toxic compounds, the cyanogenic glycosides such as linamarin and lotaustralin. It produces the two cyanogenic glycosides as a defense mechanism against attack by predators. These cyanogens are distributed widely throughout the plant, with large amounts in the leaves and the root cortex, and generally smaller amounts in the root parenchyma (interior) [2].

Intake of cassava and its products that contain large amounts of cyanogens may cause cyanide poisoning with signs and symptoms of vomiting, stomach pains, nausea, diarrhea, dizziness, weakness, headache and occasionally death [3]. Cyanide ingestion from cassava aggravates goiter and cretinism in iodine deficient areas [4] and is almost undoubtedly the cause of Konzo in eastern, central and southern Africa $[4,5]$. Tropical ataxic neuropathy (TAN) is a long-lasting condition of gradual onset that occurs in older people who eat a monotonous cassava diet. It causes loss of vision, ataxia of gait, deafness and weakness [6-8].

The cyanogenic content of cassava cultivars can be as small as less than $10 \mathrm{mg} / \mathrm{kg}$ for some cultivars and can be as high as more than $500 \mathrm{mg} / \mathrm{kg}$ fresh weight basis [9].

Nonetheless, some farmers from cassava growing countries often desire the bitter varieties as they deter pests, animals, and thieves [10]. The more-toxic varieties of cassava are a fall-back resource in times of scarcity in some places [11].

Bitter cassava varieties are more drought resilient and thus more readily available and cheaper [12]. However, owing to food shortage in times of drought, less time is sometimes available for the extra processing necessary [12].

Interestingly, enzymes present in plant are hydrolytic enzymes, which are capable of breaking down these glucosides to free cyanide. This, however, can only be made possible when there is a rupture of the cell walls for example by grating, crushing, microbial fermentation, enzymatic 
action or a combination of these, which brings the enzymes into direct contact with the glucosides [13].

Efficient cassava processing can reduce the cyanogenic glucoside content of roots of even the most potentially toxic varieties to safe levels [13].

Fermentation which is the favorite detoxifying process [14], will be used with the aim of reducing further the cyanide content to within acceptable limits (safe level) of cyanogens in cassava flour of $10 \mathrm{mg} / \mathrm{kg}$, set by the World Health Organization (WHO) [15].

\section{Materials and Methods}

\subsection{Materials}

The following apparatus were used during this research: polythene bags, a kitchen knife, distillation flask, reciprocating shaker, $125 \mathrm{~mL}$ Erlenmeyer flasks, Filter funnels, Filter paper, micro-burette and distillation apparatus. The main reagents that were used during the laboratory analysis included sodium hydroxide, $5 \%$ potassium iodide solution, $0.02 \mathrm{~N}$ silver nitrate, and distilled water.

\subsection{Harvesting and Preparation of Cassava Samples}

Cassava root tubers (seven) from Nyar-udota variety which had grown for fourteen (14) months, were obtained from the garden and peeled using a kitchen knife. The cassava root tubers were subjected to two hours of partial sun-drying and then heap fermented for varied number of days $(2,3,4,6,8,10)$. As a control, a fresh tuber that was not fermented but sun dried, was also milled and taken for analysis.

The heaping was done to allow terrestrial fermentation by growth of moulds and it was done in a grass thatched hut with clay floor to provide steady warmth.

The fermentation period was varied by obtaining a tuber from the heap after $2,3,4,6,8$ and 10 days. The fermented cassava roots were rid of the moulds by scrapping with blunt kitchen knife, pounded and then sun dried for about 8 hours. The dried cassava was then milled and taken to the Government Analytical laboratory Kampala for analysis.

\subsection{Determination of Level of Cyanides in Cassava}

The cassava samples were analyzed in the Government Analytical Laboratory (GE058/07), Kampala by the standard method of FAO [16]. In brief, the sample (10 g to $20 \mathrm{~g}$ ) was put in a distillation flask; distilled water (about 200ml) was added and allowed to stand for three hours, in order to set free all the bound hydrocyanic acid. The mixture was distilled with steam and $200 \mathrm{ml}$ of distillate was collected in a solution of $0.625 \mathrm{M}$ sodium hydroxide in water $(20 \mathrm{ml})$. The distillate was then diluted with distilled water to a volume of $250 \mathrm{ml}$.

To the distillate $(100 \mathrm{ml})$ was added potassium iodide solution $(5 \%, 8 \mathrm{ml})$ and titrated with $0.02 \mathrm{~N}$ silver nitrate $(1 \mathrm{ml}$ of $0.02 \mathrm{~N}$ silver nitrate corresponds to $1.08 \mathrm{mg}$ of hydrocyanic acid) using a micro-burette. The end point was indicated by a faint but permanent turbidity, which was easily recognized, especially against a black background.

When all the cyanide ions have reacted with the silver ions, any excess silver ions react with the iodide ions giving a precipitate of silver iodide.

$$
\begin{gathered}
\mathrm{HCN}_{(\mathrm{aq})}+\mathrm{AgNO}_{3(\mathrm{aq})} \rightarrow \mathrm{HNO}_{3(\mathrm{aq})}+\mathrm{AgCN}_{(\mathrm{aq})} \\
\mathrm{Ag}^{+}{ }_{(\mathrm{aq})}+\mathrm{I}^{-}{ }_{(\mathrm{aq})} \rightarrow \mathrm{AgI}_{(\mathrm{s})}
\end{gathered}
$$

Excess

\subsection{Data Analysis}

A graph was generated from the results of laboratory analysis using Microsoft Excel. One-way ANOVA was used to analyze the variation of level of hydrogen cyanide with duration of fermentation.

\section{Results and Discussion}

Variation of level of hydrogen cyanide with fermentation days in Nyar-udota cassava variety

The level of hydrogen cyanide in Nyar-udota cassava variety that was fermented for varying number of days steadily decreased from 0 to 3 days of fermentation followed by a gentle decrease from 3 to 4 days of fermentation and then fairly constant values from 4 to 10 days of fermentation (Figure 1). Hydrogen cyanide content in the dried Nyarudota cassava sample on Day 0 (unfermented) was the highest $(52.63 \mathrm{mg} / \mathrm{kg})$ while the value on the tenth day of fermentation $(18.58 \mathrm{mg} / \mathrm{kg})$ was the least.

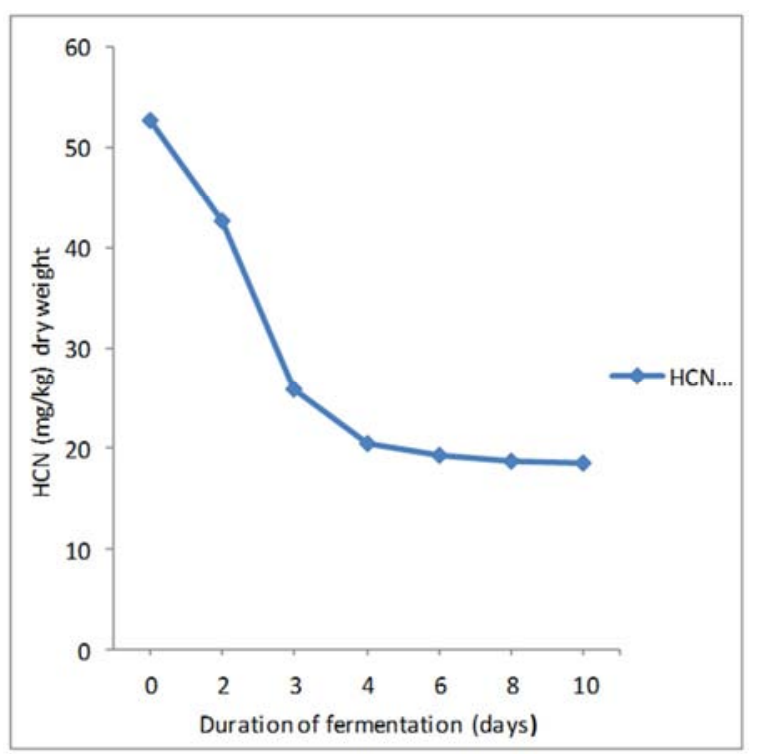

Figure 1. Variation of level of hydrogen cyanide with duration of fermentation in Nyar-udota cassava variety.

Generally, the level of the hydrogen cyanide decreased significantly $\left(\mathrm{F}_{(1,12)}=19.46, \mathrm{p}=8.49 \times 10^{-4}\right)$ with fermentation days, with a percentage decrease of up to $64.7 \%$ on the tenth day of fermentation.

These findings confirm what was reported by Kobawila 
[17] and Agbor-Egbe [18] that cyanide content in cassava roots decreases progressively during fermentation.

Fermentation probably causes more cell rupture which easily brings about contact between substrate cyanoglycosides and the enzymes thus leading to the breakdown of cyanoglycosides to release free HCN [14]. Heap fermentation also produces heat that volatilizes free hydrogen cyanide [14]. Although, the results by Lambri [19] and Bradbury [20] showed that fermentation temperature was not significant as no consistent differences were shown between 30 or $35^{\circ} \mathrm{C}$ fermentation temperatures. However, free hydrogen cyanide which is volatile at $25.7^{\circ} \mathrm{C}$ would steadily evaporate by the warmth generated by fermentation [14, 21].

According to Westby [21], the crucial features of good processing are sufficient tissue disruption to allow endogenous linamarase to react with linamarin and then favourable conditions for the breakdown of acetone cyanohydrin, or, conditions under which the compound will volatize spontaneously. In the case of the heap-fermented products, microbial growth contributes to cyanogens reduction by softening the cassava roots which enhances the contact between endogenous linamarin and linamarase [22].

Natural fermentation is characterized by a series of microorganisms in which the predominant microbial groups are lactic acid bacteria (LAB) and yeasts [23-25]. The most frequent LAB species are Lactobacillus manihotivorans and Lactobacillus plantarum [26]. L. manihotivorans is present only during the first period of fermentation, when it may participate in accelerating the rate of degrading starch [24], leading to contact between linamarase and cyanogenic glycosides, thus, reducing its level as fermentation progresses. Meanwhile, L. plantarum, which is present during all the steps of the fermentative process, contributes to acidify the substrate. Therefore, as the fermentation progresses, a gradual reduction in the number of microorganisms due to the increased acidity of the medium [27], slows down the fermentation process until it finally stops (Figure 1).

\section{Conclusions}

Fermentation decreases the level of the hydrogen cyanide significantly and the decrease varies with period of fermentation.

\section{Acknowledgements}

Glory to the almighty God. Special recognition to Prof. Christine Dranzoa, Vice Chancellor, Muni University. The following are also recognized: Mr. Dan Lema, Mr. Geoffrey Cwothembu, Mr. Naftali Ucama-Giu, Mr. Howard Jaloch, Ms. Jackline Ayenya, Mr. Francis Ocan, Mr. Jonathan Brady WagenYesu, Ms Gladys Atimango, Mr Patrick Odubi, Mr. William C. O. O Uchaki, Mr. Nzima James Alimudua, Mr. Ezra Okecha (RIP) and lastly Mrs Zila Adubango (RIP), my lovely mum, to whom this paper is dedicated.

\section{References}

[1] J. H. Cock, "Cassava: New Potential for a Neglected Crop," Westview Press, Boulder, CO, USA, 1985.

[2] J. H. Bradbury, and W. D. Holloway, "Chemistry of Tropical Root Crops: Significance for Nutrition and Agriculture in the Pacific," Australian Centre for International Agricultural Research, Monograph No. 6, Canberra, Australia, 1988.

[3] A. Akintonwa, O. Tunwashe, and A. Onifade, "Fatal and nonfatal acute poisoning attributed to cassava-based meal," Acta Horticulturae, 375, 285-288, 1994.

[4] F. Delange, L. O. Ekpechi, and H. Rosling, "Cassava cyanogenesis and iodine deficiency disorders," Acta Horticulture, 375, 289-293, 1994.

[5] M. Ernesto, A. P. Cardoso, D. Nicala, E. Mirione, F. Massaza, J. Cliff, M. R. Haque and J. Bradbury, "Persistent konzo and cyanide toxicity from cassava in Northern Mozambique," Acta Tropica, 82: 357-362, 2002.

[6] B. O. Osuntokun, "Chronic cyanide intoxication of dietary origin and a degenerative neuropathy in Nigerians," Acta Horticulturae, 375, 311-321, 1994.

[7] W. P. Howlett, "Konzo; a new human disease entity," Acta Horticulturae, 375, 323-329, 1994.

[8] A. O. Onabolu, O. S. A. Oluwole, M. Bokanga, and H. Rosling, "Ecological variation of intake of cassava food and dietary cyanide load in Nigerian communities," Public Health Nutrition, 4, 871-876, 2001.

[9] G. M. O'Brien, C. C. Wheatley, C. Iglesias, and N. H. Poulter, "Evaluation, modification, and comparison of two rapid assays for cyanogens in cassava," Journal of the Science of Food and Agriculture, 65, 391-399, 1994.

[10] C-K. Linley, K. Chrissie, J. Ngoma, F. Chipungu, J. Mkumbira, S. Simukoko, and J. Jiggins, "Bitter cassava and women: an intriguing response to food security," LEISA Magazine, 18 (4), 2002.

[11] Food and Agriculture Organization of the United Nations, "Roots, tubers, plantains and bananas in human nutrition", Rome, 1990, Ch. 7 "Toxic substances and antinutritional factors", first paragraph.

[12] A. P. Cardoso, E. Mirione, M. Ernesto, F. Massaza, J. Cliff, M. R. Haque, and J. H Bradbury, "Processing of cassava roots to remove cyanogens," Journal of Food Composition and Analysis, 18, 451-460, 2005.

[13] A. Akintonwa, and O. L. Tunwashe, "Fatal cyanide poisoning from cassava-based meal," Human \& Experimental Toxicology, 11, 47-49, 1992.

[14] M. Andama, and J. B. Lejju, "Potential of Fermentation in Detoxifying Toxic Cassava Root Tubers," Journal of Agricultural Science and Technology, A 2, 1182-1188, 2012.

[15] FAO/WHO, "Joint FAO/WHO Food Standards Programme," Codex Alimentarius Commission XII, Supplement 4, FAO, Rome, Italy, 1991.

[16] FAO, "Processing and utilization of Root and Tuber Crops," FIAT PANIS; Rome, 2000. 
[17] S. C. Kobawila, D. Louembe, S. Keleke, J. Hounhouigan, and C. Gamba, "Reduction of the cyanide content during fermentation of cassava roots and leaves to produce bikedi and ntoba mbodi, two food products from Congo," African Journal of Biotechnology, 4 (7), 689-696, 2005.

[18] T. Agbor-egbe, I. L. Mbome, and S. Treche, "The effectiveness of cyanogen reduction during cassava processing into miondo," In: T Agbor-Egbe, D Griffon, S Treche (eds.), Transformation alimentaire du manioc, Editions Orstom, pp. 307-318, 1995.

[19] M. Lambri, D. M. Fumi, A. Roda, and M. D. F. Dante, "Improved processing methods to reduce the total cyanide content of cassava roots from Burundi," African Journal of Biotechnology, 12 (19), 2685-2691, 2013.

[20] J. H. Bradbury, "Simple wetting method to reduce cyanogens content of cassava flour," Journal of Food Composition and Analysis, 19, 388-393, 2006.

[21] A. Westby, "Cassava Utilization, Storage and Small-scale Processing," In: CAB International 2002. Cassava: Biology, Production and Utilization (eds R. J. Hillocks, J. M. Thresh and A. C. Bellotti). pp. 281-300, 2002.

[22] A. J. Essers, C. Ebong, R. M. van der Grift, M. J. R. Nout, W. Otim-Nape, and H. Rosling, "Reducing cassava toxicity by heap fermentation in Uganda," International Journal of Food Sciences and Nutrition, 46, 125-136, 1995.

[23] C. Figueroa, A. M. Davila, and J. Pourquié, "Lactic acid bacteria of the sour cassava starch fermentation," Letters in Applied Microbiology, 21, 126-130, 1995.

[24] F. Ampe, A. Sirvent, and N. Zakhia, "Dynamics of the microbial community responsible for traditional sour cassava starch fermentation studied by denaturing gradient gel electrophoresis and quantitative rRNA hybridization," International Journal of Food Microbiology, 65, 45-54, 2001.

[25] M. P. Cadena, E. C. Villarraga, D. E. Luján, and Salcedo, J. G. "Evaluación de la agroindustria del almidón agrio de yuca (Manihot esculenta Crantz) en Cordoba y Sucre," Temas Agrarios, 11, 43-53, 2006.

[26] O. N. Ben, F. Ampe, M. Raimbault, J. P. Guyot, and P. Tailliez, "Molecular diversity of lactic acid bacteria from cassava sour starch (Colombia)," Systematic and Applied Microbiology, 23, 285-291, 2000.

[27] O. B. Oyewole, "Characteristics and significance of yeasts' involvement in cassava fermentation for fufu production," International Journal of Food Microbiology, 65, 213-218, 2001. 